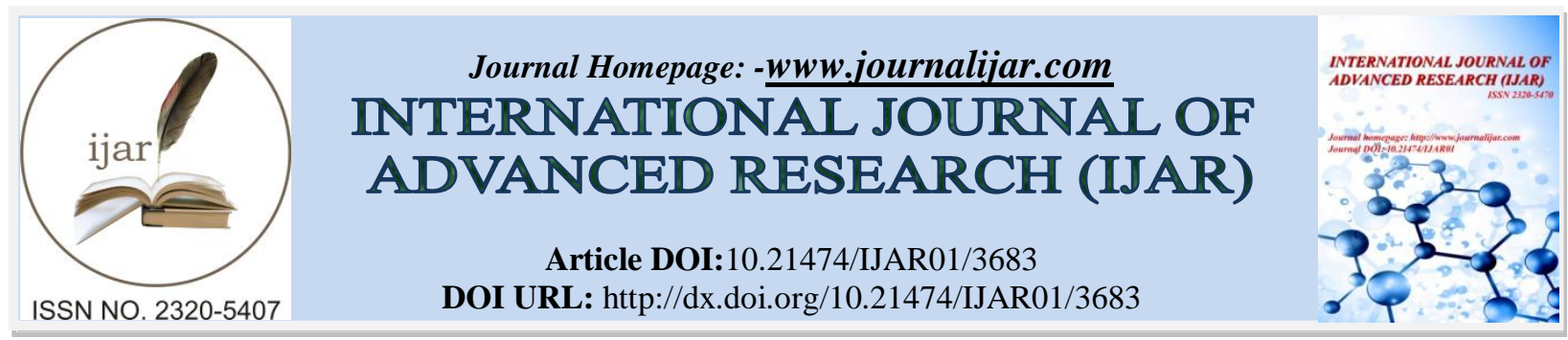

RESEARCH ARTICLE

\title{
ISOLATION OF ENTEROBACTERIACEAE FROM RAW SEAFOODS SOLD IN FISH MARKETS IN EASTERN PROVINCE OF SAUDI ARABIA.
}

Mohamed Ibrahim M.A*, SamiShabeeb Al Shabeeb, Ghamri H. Al Ramadhan and Peer Mohamed Imran. Fisheries Research Center, Deputy Ministry for Fisheries, Ministry of Environment, Water and Agriculture, Kingdom of Saudi Arabia.

\section{Manuscript History}

Received: 12 January 2017

Final Accepted: 09 February 2017

Published: March 2017

Key words:-

Enterobacteriaceae, Seafoods, API, Pathogenic bacteria, Preventive measures, Hygiene practices

\section{Manuscript Info}

\begin{abstract}
Aim of this investigation is to provide the general information about prevalence of members of Enterobacteriaceae in raw seafoods sold in fish markets in Eastern province of Saudi Arabia. Studies were carried out to isolate and identify different bacterial species belongs to the family of Enterobacteriaceae in 448 seafood samples comprising Fishes (353), Prawns (49) and Cuttlefishes (46), collected during the period from January 2015 until May 2016. Bacterial isolates were characterized on specific culture media and further confirmed using API 20E Strips and identified by "api web". Out of 448 samples analysed, $304(67.85 \%)$ samples showed positive isolation of Enterobacteriaceae. Morganellamorganii showed highest prevalence (18.52\%), followed by Proteussp (12.27\%), Citrobactersp (8.03\%), Enterobactersp (6.69\%), Providenciasp (5.58\%), Hafniaalvei (4.46\%), Escherichia coli (4.24\%), Klebsiellasp (2.90\%), Rahnellaaquatilis (2\%), Serratialiquefaciens (1.78\%) and Pantoeaagglomerans (1.33\%). The presence of these organisms in the fresh seafood samples showed that the source of contamination may be from environment, catching, unhygienic handling and transportation. Thus it is strongly recommended that the improvements in handling and processing are needed to minimize the prevalence of pathogenic bacteria by implementing preventive measures and application of appropriate procedures for hygiene practices to monitor the quality of raw seafoods.
\end{abstract}

Copy Right, IJAR, 2017,. All rights reserved.

\section{Introduction:-}

Fish is a valuable and nutritious food, and an essential source of high quality and cheap animal protein crucial to balance of diets in marginally food secure communities (United Nation, 2004). Production of Fish and Shellfish by aquaculture is the fastest growing sector of world food economy. World aquaculture output has been growing at $11 \%$ per annum during the past decade and has reached 33.3 million tonnes in the year 1999 (Biradaret al, 2001).

Unlike meat and poultry, fish are more liable to contamination with pathogenic bacteria from human reservoirs which may contaminate the water depending on the fishing and also may be further contaminated during handling, processing and packaging. While the muscle fleshes of fish, which is the main edible part is normally sterile but microorganisms can penetrate from the skin and the gut to the flesh (FAO, 1983).

Corresponding Author:- Mohamed Ibrahim M.A.

Address:-Fisheries Research Center, Deputy Ministry for Fisheries, Ministry of Environment, Water 1711 
Fishery products have been recognized as a major carrier of food-borne pathogens. The contamination can occur prior to harvest, during harvest and processing operations, distribution, storage and preparation of the product. In a simplified overview, poor quality products, spoiled or decomposed are rarely responsible for food poisoning because they are usually discarded before consumption. Food poisoning in seafood products such as scombroid or histamine poisoning, normally is the result of mishandling during or after preparation. The microbial flora of seafood is related to the environment from which the fish are harvested (Wekellet al, 1994; Falana, 2005).

Fresh fish is a very perishable product and spoil due to microbiological activity, chemical oxidation of lipids and autolysis. However, microbial spoilage is the main mechanism affecting fresh fish quality. As the bacteria grow they utilize nutrients and produce by-products. It is well established that the accumulation of metabolic products is the primary cause of the organoleptic rejection of fresh fish. It is also known that spoilage is caused only by a fraction of the initial microbial population, known as specific spoilage organisms (SSO), which produce metabolites responsible for off-flavors and cause the organoleptic rejection of the product. The fraction of the initial micro-biota that dominate and the metabolic products that are produced are determined mostly by the temperature and atmospheric conditions during storage (Gram and Huss, 1996).

The Enterobacteriaceae count is considered as an index to determine the seafood quality. Some human pathogens such as Escherichia coli, Klebsiellasp, Salmonellasp, Citrobactersp and Proteus sp, when isolated from fish and fish products gives an identification about environmental fecal pollution of fish. These organisms have been found to survive and multiply in the gut, mucus and tissues of fish and that render fish acting as potential vector of human disease over long periods (Onyangoet al, 2009; Wogu and Maduakol, 2010).

Contamination of seafood with Salmonella is a major public health concern. Salmonellosis is a worldwide problem responsible for food poisoning outbreaks but it is mainly difficult to determine whether the contamination of fishes occurred in their aqueous habitat or during their handling and marketing (Etzelet al, 1998). Coliforms and Fecal coliforms in fish demonstrate the level of pollution of their environment because these organisms are not the normal bacterial flora in fish. (Cohen and Shuval, 1973).

Therefore, the intention of this study is to determine the contamination level of seafood samples with Enterobacteriaceae collected from the Eastern province of Saudi Arabia. And to take recommendations to reduce risk associated with the consumption of seafood.

\section{Materials and Methods:-}

A total of 448 samples comprising of Fishes (353), Prawns (49) and Cuttlefishes (46) were randomly collected from retail and wholesale fish markets in Dammam during the period from January 2015 until May 2016. The collected samples were individually kept in sterile polyethylene bags embedded with ice and transported rapidly to the laboratory in an insulated box.

\section{Sample processing for Bacteriological Examination:-}

Bacteriological analyses of collected seafoods were performed within 2 hours of sampling. All media used in the present study were from Oxoid, U.K. and prepared according to the standard procedures. Media were sterilized by autoclaving at $121^{\circ} \mathrm{C}$ at $15 \mathrm{psi}$ pressure for 15 minutes, unless otherwise specified. Sterility of the media was checked by incubating at $37^{\circ} \mathrm{C}$ for 24 hours. The microbiological analysis was performed as per the standard methods adopted from the Online Bacteriological Analytical Manual, USFDA (BAM $8^{\text {th }}$ edition Online).

\section{Salmonella species:-}

$25 \mathrm{~g}$ of the sample was homogenized in $225 \mathrm{ml}$ of Lactose Broth (LB) and incubated overnight at $37^{\circ} \mathrm{C}$. After the initial pre enrichment step, samples were selective enriched in Tetrathionate Broth (TTB) at $37^{\circ} \mathrm{C}$ and Rappaport Vassiliadis (RV) medium at $42^{\circ} \mathrm{C}$ and incubated overnight. A loopful of growth from each of these media was streaked on Bismuth Sulphite Agar (BSA), Xylose Lysine Deoxycholate Agar (XLDA) and Hektoen Enteric Agar (HEA). After 24 (HEA, XLDA) - 48 (BSA) hours of incubation at $37^{\circ} \mathrm{C}$, both atypical and typical colonies were picked up, purified and identified further by subsequent biochemical tests which included Gram staining, Motility, Oxidase production and then identified at the genus and species level using API 20E (Biomerieux, France) test kits. The identification was obtained by using the identification software "api web". 


\section{Other Enterobacteriaceae:-}

$25 \mathrm{~g}$ of the sample was homogenized in $225 \mathrm{ml}$ of sterile physiological saline in a filter stomacher bag and made in to slurry using the BagMixer® (Interscience, France) and the diluted samples were plated on MacConkey Agar. After 24 hours of incubation at $37^{\circ} \mathrm{C}$, both pink and colourless colonies were picked up, purified and identified further by subsequent biochemical tests which included Gram staining, Motility, Oxidase production and then identified at the genus and species level using API 20E (Biomerieux, France) test kits. The identification was obtained by using the identification software "api web".

\section{Results and Discussion:-}

The Enterobacteriaceae are all occurring on fish products as a result of contamination from the animal/human reservoir. This contamination has normally been associated with fecal contamination or pollution of natural water or water environments, where these organisms may survive for a long time (months) or through direct contamination of products during processing (FAO).

This study was conducted to determine the incidence of Enterobacteriaceae in Seafoods (353 Fishes, 49 Prawn and 46 Cuttlefish) for sale in wholesale and retail outlets of fish markets in Eastern province of Saudi Arabia. The results related to the incidence and identification at the species level of Enterobacteriaceae from Fishes, Prawn and Cuttlefish are summarized in Table 1. The overall percentages of prevalent bacterial species are shown in Table 2.

Out of 448 samples analysed, 304 (67.85\%) samples showed positive isolation of Enterobacteriaceae. The ranges of incidence levels of Enterobacteriaceae were from Fishes 233 out of 353 (66\%), Prawn 44 out of 49 (89.79\%) and Cuttlefish 27 out of $46(58.69 \%)$.

The obtained results were revealed that the dominant bacterial species occurred most frequently in the three types of seafood samples includes Morganellamorganii with 83 isolates (18.52\%), followed by Proteusspp with 55 isolates (12.27\%), Citrobacterspp with 36 isolates (8.03\%), Enterobacterspp with 30 isolates (6.69\%), Providenciaspp with 25 isolates (5.58\%), Hafniaalvei with 20 isolates (4.46\%), Escherichia coli with 19 isolates (4.24\%), Klebsiellaspp with 13 isolates (2.90\%), Rahnellaaquatilis with 9 isolates (2\%), Serratialiquefaciens with 8 isolates (1.78\%) and the lower isolate was Pantoeaagglomerans with 6 isolates (1.33\%).

Salmonella was not detected in any of the samples analysed in this study, which was in agreement with previous studies (Popovicet al, 2010; Rodriquez et al, 2011; Figenet al, 2014) in seafood products. Conversely, different workers (Shabarinathet al, 2007; Kumar et al, 2009; Bakret al, 2011) reported varying incidence rates of Salmonella in seafood.

Morganellamorganii is widely distributed in nature, commonly found in the environment and the intestinal tracts of humans, mammals and reptiles as a part of the normal flora. Generally Morganellamorganii can act as an opportunistic pathogen that mainly causes wound and urinary tract infections. The drug resistance of Morganellamorganii is increasing in recent years, which often results in Clinical treatment failure (Hui Liu et al, 2016). In the present study Morganellamorganii showed highest prevalent (18.52\%) in all the analysed seafoods. In a study conducted by SureeratPhuvasate (2008), he clearly demonstrated the ability of Morganellamorganii to produce Histamine in fish samples. Histamine is a biogenic amine formed through the decarboxylation of the amino acid histidine by the enzyme histidine decarboxylase. Consumption of fish containing histamine may result in illness known as Scombroid poisoning with a variety of symptoms, including rash, facial flushing, sweating, vomiting, diarrhea, head ache, burning sensation and metallic taste in the mouth.

Proteus sp. were involved in the spoilage of seafoods which can result in potential health hazard to the consumers. It can cause enteric infection in humans, summer diarrhea in infants, sinusitis, otitis as well as urinary tract infections (Bryan 1980; Varnam and Evas, 1991). The isolation of Proteus sp. from fish samples has been reported in previous studies by Tosunet al (2016). Sanaa O. Yagoub (2009) isolated Proteussp in fish with an incidence of $10.2 \%$. In the present study, the percentages of Proteus mirabilis and Proteus vulgaris were $7.58 \%$ and $4.68 \%$ respectively. Some investigations involve Proteus genus as an indicator of fecal contamination in marine fish, although their use as an indicator is not very common (ILSI, 2011).

In this study, members of Citrobacter were identified, represented by species in the ranges of Citrobacterfreundii (4.24\%), Citrobacterbraakii (2.67\%) and Citrobacterkoserii (1.11\%). Olugbojoet al (2015), detected the presence of 
Citrobactersp in fish samples of commercial importance collected from Nigeria. In a study conducted by Tosunet al (2016), Citrobactersp showed highest prevalence (45.56\%) among all other Enterobacteriaceae from Horse Mackerel fish sold in public markets of Istanbul, Turkey. Citrobactersp are widely distributed in soil, water, food and the intestinal tract of humans and animals. They make up the normal flora of the human gut and were previously considered as a purely environmental contaminants or non-pathogenic colonizers, but known to be opportunistic pathogens, as they can cause serious infections, sepsis, food borne outbreaks of gastroenteritis, respiratory infections and urinary tract infections, especially in high-risk groups such as infants and immune compromised adults (Rusulet al, 1991; Dos santoset al, 2015).

The Enterobactersp can be found in soil, water, sewage, intestinal tract of man and animals (Banwart, 1989). In the present study, several species of Enterobacter has been isolated which includes Enterobacter cloacae (2.67\%), Enterobacter aerogenes (2.23\%), Enterobacteramnigenus (1.11\%) and Enterobactersakazakii (0.66\%). In a study conducted by Mai F. Elsheriefet al (2014), he isolated Enterobactersp along with other members of Enterobacteriaceae from the farmed and retailed fishes of Tilapia and Mugilcephalus. Enterobactersp can act as opportunistic pathogens that rarely cause primary diseases in humans. They are described as agents associated with respiratory infections, skin, urinary tract, bones, joints, central nervous system and gastro intestinal tract infections (Dos Santos et al, 2015).

In this study, members of Providencia were isolated, identified and represented by species in the percentages of Providenciastuartii (2.67\%), Providenciarettgeri (1.56\%) and Providenciaalcalifaciens (1.33\%). Sanaa O. Yagoub (2009), isolated Providencia app along with other members of Enterobacteriaceae including, Esherichia coli, Enterobactersp, Klebsiellasp, Citrobactersp, Salmonellasp, Shigella sp, Serratiasp and Proteussp from raw fish sold in fish market in Khartoum state of Sudan. Providenciasp are generally considered to be commensals in the gastrointestinal tract of humans, warm blooded animals, often also in soil and sewage water. Providenciarettgeri, Providenciastuartii and Providenciaalcalifaciens has been isolated from samples of human feces, either as part of the human intestinal microbiota as well as a cause of gastric disorder, such as traveler's diarrhea. In 2001, Providenciaalcalifaciens was reported in a major outbreak of food borne illness among children in japan. They can act as opportunistic pathogen involved in urinary tract infections, keratitis, dacryocystitis, conjunctivitis and endophthalmitis. The bacteria Providenciastuartii is reported as more resistant species of the family Enterobacteriaceae. The emerging of resistance in Providenciasp is a clinical concern as it may lead to increased treatment cost and delays in treatment, which can be fatal to the patient (Dost Santos et al, 2015).

Hafniaalvei, a member of the family Enterobacteriaceae and the only species of the genus Hafniadescribed, is part of the human gastrointestinal flora, but can be found in environmental habitats such as surface water and food. Hafniaalvei is normally considered as a colonizing organism and rarely appears to be a pathogen. Recent findings suggest that it is a rare but may contribute to opportunistic infections in humans apart from diarrhea; it can cause extra intestinal infections such as septicaemia, liver abscess, peritonitis and pneumonia (Podschunet al, 2001; Dos Santos et al., 2015). In the present investigation, the prevalence range of Hafniaalvei is around $4.46 \%$ in seafoods, followed by Escherichia coli with the percentage of $4.24 \%$ and members of Klebsiellasp, represented by its species in the ranges of Klebsiellaterrigena (1.56\%) and Klebsiellapneumoniae (1.33\%). Isolation of Escherichia coli and Klebsiellasp from the seafood samples analysed in this study was in agreement with the previous studies done by different workers (Yagoub, 2009; Mai F. Elsheriefet al, 2014; Romero Jarero Jorge, 2016; Tosunet al, 2016) who reported varying incidence rates of such organisms in seafoods.

Infections associated with Escherichia coli through the ingestion of seafoods are directly related to fecal contamination. Escherichia coli is normally present in the intestinal flora of humans and warm-blooded animals which may transfer to the foods due to the poor hygienic conditions, cross contamination or contaminated water (Huss et al, 2004; Renata Albuquerque costa, 2013). Klebsiellasp can also act as an opportunistic pathogen that cause wide range of infections including foodborne outbreaks of gastroenteritis, urinary tract infections, pneumonia, bacteremia, neonatal sepsis and wound infections (Rahkiaet al, 1998; Podschunet al, 1998).

In the present study members of Enterobacteriaceae such as Rahnellaaquatilis, Serratialiquefaciens and Pantoeaagglomerans were isolated in the ranges of $2 \%, 1.78 \%$ and $1.33 \%$ respectively from the analysed seafoods. All the above organisms can act as opportunistic pathogen in humans. Rahnellaaquatilis is typically associated with fresh water, since been isolated from blood, surgical wounds, urine, sputum, bronchial washings and stool, usually in immune compromised patients or in young children (KaleyTash, 2004). Serratialiquefaciens also an opportunistic 
pathogen which is capable of colonizing a wide variety of surfaces in water, soil, the digestive tracts of rodents, plants, insects, fish and humans (Grimont and Grimont, 1978). Pantoeaagglomerans inhabits plants, soil, and water, reported as both commensal and pathogen of animals and humans. They rarely cause disease in healthy individuals, such as septic arthritis, outbreak secondary to contaminated parental nutrition, occupational respiratory infections and skin allergy (Maria Carla Libertoet al, 2009).

Most of the Enterobacteriaceae members isolated and identified in this study were comes under the group of Coliforms and Fecal Coliforms. Austin and Austin (1985) have demonstrated the presence of Escherichia coli, Enterobactersp, Citrobactersp, Salmonella sp, Proteus sp, in fish that lives in contaminated marine water by domestic waste water. Priyanka Rani Majumdaret al (2014), stated that the untreated and the improper way of sewage disposal system in the water body is one of the main sources for microbial water contamination which results in the accumulation of these bacterial pathogenic species in the commercial edible fishes. Moreover, unhygienic handling by infected people or healthy carriers, during the capture, transport and processing may also act as a source of contamination by pathogenic organisms in seafoods.

Table 1:-List of Bacterial species isolated from Fishes, Prawn and Cuttlefish.

\begin{tabular}{|c|c|c|}
\hline FISHES & PRAWN & CUTTLEFISH \\
\hline Enterobacter cloacae & Enterobacter aerogenes & Proteus mirabilis \\
Enterobacter aerogenes & Enterobacteramnigenus & Protgaris \\
Enterobacteramnigenus & Enterobacter cloacae & Providenciastuartii \\
Enterobactersakazakii & Enterobactersakazakii \\
Citrobacterfreundii & Citrobacterfreundii & Morganellamorganii \\
Citrobacterbraakii & Citrobacterbraakii & Hafniaalvei \\
Citrobacterkoserii & Citrobacterkoserii & Escherichia coli \\
Providenciastuartii & Proteus vulgaris \\
Providenciaalcalifaciens & Proteus mirabilis & Klebsiellapneumoniae \\
Providenciarettgeri & Morganellamorganii & Rahnellaaquatilis \\
Proteus mirabilis & Escherichia coli & Hafniaalvei \\
Proteus vulgaris & Rahnellaaquatilis & \\
Klebsiellaterrigena & Serratialiquefaciens & \\
Klebsiellapneumoniae & Pantoeaagglomerans & \\
Morganellamorganii & & \\
Escherichia coli & & \\
Hafniaalvei & & \\
Rahnellaaquatilis & & \\
Pantoeaagglomerans & & \\
\end{tabular}


Table2:- Prevalence of Bacterial species among Fishes, Prawn and Cuttlefish.

\begin{tabular}{|c|c|c|c|c|c|c|c|}
\hline \multirow[t]{2}{*}{$\begin{array}{l}\text { S. } \\
\text { No }\end{array}$} & \multirow[t]{2}{*}{$\begin{array}{l}\text { Bacterial } \\
\text { Isolates }\end{array}$} & \multirow[t]{2}{*}{$\begin{array}{l}\text { Bacteria } \\
\text { l Genus }\end{array}$} & \multicolumn{3}{|c|}{$\begin{array}{c}\text { Overall No. (\%) of Prevalence in } \\
\text { Samples }\end{array}$} & \multirow{2}{*}{$\begin{array}{c}\text { No. }(\%) \text { of } \\
\text { Prevalence for } \\
\text { Total } 448 \\
\text { Samples }\end{array}$} & \multirow{2}{*}{$\begin{array}{c}\text { No. }(\%) \text { of } \\
\text { Prevalence of } \\
\text { Bacterial } \\
\text { Genus }\end{array}$} \\
\hline & & & Fishes (353) & $\begin{array}{c}\text { Prawn } \\
(49)\end{array}$ & $\begin{array}{c}\text { Cuttlefis } \\
\text { h }(46)\end{array}$ & & \\
\hline 01. & $\begin{array}{l}\text { Morganellamorg } \\
\text { anii }\end{array}$ & $\begin{array}{l}\text { Morgane } \\
\text { llaspp }\end{array}$ & $\begin{array}{c}63(17.84 \\
\%)\end{array}$ & $\begin{array}{c}14 \\
(28.57 \%) \\
\end{array}$ & $\begin{array}{c}06 \\
(13.04 \%) \\
\end{array}$ & $83(18.52 \%)$ & $83(18.52 \%)$ \\
\hline 02. & $\begin{array}{l}\text { Proteus } \\
\text { mirabilis }\end{array}$ & \multirow[t]{2}{*}{$\begin{array}{l}\text { Proteus } \\
\text { spp }\end{array}$} & $28(07.93 \%)$ & $\begin{array}{c}02 \\
(04.08 \%) \\
\end{array}$ & $\begin{array}{c}04 \\
(08.69 \%)\end{array}$ & $34(07.58 \%)$ & \multirow[t]{2}{*}{$55(12.27 \%)$} \\
\hline 03. & Proteus vulgaris & & $14(03.96 \%)$ & $\begin{array}{c}03 \\
(06.12 \%) \\
\end{array}$ & $\begin{array}{c}04 \\
(08.69 \%) \\
\end{array}$ & $21(04.68 \%)$ & \\
\hline 04. & $\begin{array}{l}\text { Citrobacterfreun } \\
\text { dii }\end{array}$ & \multirow{3}{*}{$\begin{array}{l}\text { Citrobact } \\
\text { erspp }\end{array}$} & $16(04.53 \%)$ & $\begin{array}{c}03 \\
(06.12 \%) \\
\end{array}$ & --- & $19(04.24 \%)$ & \multirow[t]{3}{*}{$36(08.03 \%)$} \\
\hline 05. & $\begin{array}{l}\text { Citrobacterbraa } \\
\text { kii }\end{array}$ & & $\begin{array}{c}07(01.98 \\
\%) \\
\end{array}$ & $\begin{array}{c}03 \\
(06.12 \%) \\
\end{array}$ & $\begin{array}{c}02 \\
(04.34 \%) \\
\end{array}$ & $12(02.67 \%)$ & \\
\hline 06. & $\begin{array}{l}\text { Citrobacterkoser } \\
i i\end{array}$ & & $04(01.13 \%)$ & $\begin{array}{c}01 \\
(02.04 \%)\end{array}$ & --- & $05(01.11 \%)$ & \\
\hline 07. & $\begin{array}{l}\text { Enterobacter } \\
\text { cloacae }\end{array}$ & \multirow{4}{*}{$\begin{array}{l}\text { Enteroba } \\
\text { cterspp }\end{array}$} & $11(03.11 \%)$ & $\begin{array}{c}01 \\
(02.04 \%)\end{array}$ & --- & $12(02.67 \%)$ & \multirow[t]{4}{*}{$30(06.69 \%)$} \\
\hline 10. & $\begin{array}{l}\text { Enterobacter } \\
\text { aerogenes }\end{array}$ & & $06(01.69 \%)$ & $\begin{array}{c}04 \\
(08.16 \%)\end{array}$ & --- & $10(02.23 \%)$ & \\
\hline 08. & $\begin{array}{l}\text { Enterobacteram } \\
\text { nigenus }\end{array}$ & & $03(00.84 \%)$ & $\begin{array}{c}02 \\
(04.08 \%) \\
\end{array}$ & --- & $05(01.11 \%)$ & \\
\hline 09. & $\begin{array}{l}\text { Enterobactersak } \\
\text { azakii }\end{array}$ & & $02(00.56 \%)$ & $\begin{array}{c}01 \\
(02.04 \%) \\
\end{array}$ & --- & $03(00.66 \%)$ & \\
\hline 11. & $\begin{array}{l}\text { Providenciastua } \\
\text { rtii }\end{array}$ & \multirow{3}{*}{$\begin{array}{l}\text { Providen } \\
\text { ciaspp }\end{array}$} & $09(02.54 \%)$ & --- & $\begin{array}{c}03 \\
(06.52 \%)\end{array}$ & $12(02.67 \%)$ & \multirow[t]{3}{*}{$25(05.58 \%)$} \\
\hline 13. & $\begin{array}{l}\text { Providenciarettg } \\
\text { eri }\end{array}$ & & $06(01.69 \%)$ & --- & $\begin{array}{c}01 \\
(02.17 \%) \\
\end{array}$ & $07(01.56 \%)$ & \\
\hline 12. & $\begin{array}{l}\text { Providenciaalca } \\
\text { lifaciens }\end{array}$ & & $06(01.69 \%)$ & --- & --- & $06(01.33 \%)$ & \\
\hline 14. & Hafniaalvei & $\begin{array}{l}\text { Hafniasp } \\
p\end{array}$ & $13(03.68 \%)$ & $\begin{array}{c}03 \\
(06.12 \%) \\
\end{array}$ & $\begin{array}{c}04 \\
(08.69 \%) \\
\end{array}$ & $20(04.46 \%)$ & $20(04.46 \%)$ \\
\hline 15. & Escherichia coli & $\begin{array}{l}\text { Escheric } \\
\text { hia spp }\end{array}$ & $14(03.96 \%)$ & $\begin{array}{c}04 \\
(08.16 \%) \\
\end{array}$ & $\begin{array}{c}01 \\
(02.17 \%) \\
\end{array}$ & $19(04.24 \%)$ & $19(04.24 \%)$ \\
\hline 16. & $\begin{array}{l}\text { Klebsiellaterrige } \\
\text { na }\end{array}$ & \multirow[t]{2}{*}{$\begin{array}{l}\text { Klebsiell } \\
\text { aspp }\end{array}$} & $07(01.98 \%)$ & --- & --- & $07(01.56 \%)$ & \multirow[t]{2}{*}{$13(02.90 \%)$} \\
\hline 17. & $\begin{array}{l}\text { Klebsiellapneum } \\
\text { oniae }\end{array}$ & & $05(01.41 \%)$ & --- & $\begin{array}{c}01 \\
(02.17 \%)\end{array}$ & $06(01.33 \%)$ & \\
\hline 18. & $\begin{array}{l}\text { Rahnellaaquatili } \\
S\end{array}$ & $\begin{array}{l}\text { Rahnella } \\
\text { spp }\end{array}$ & $07(01.98 \%)$ & $\begin{array}{c}01 \\
(02.04 \%) \\
\end{array}$ & $\begin{array}{c}01 \\
(02.17 \%) \\
\end{array}$ & $09(02.00 \%)$ & $09(02.00 \%)$ \\
\hline 19. & $\begin{array}{l}\text { Serratialiquefaci } \\
\text { ens }\end{array}$ & $\begin{array}{l}\text { Serratias } \\
p p\end{array}$ & $07(01.98 \%)$ & $\begin{array}{c}01 \\
(02.04 \%) \\
\end{array}$ & --- & $08(01.78 \%)$ & $08(01.78 \%)$ \\
\hline 20. & $\begin{array}{l}\text { Pantoeaagglome } \\
\text { rans }\end{array}$ & $\begin{array}{l}\text { Pantoeas } \\
\text { pp }\end{array}$ & $05(01.41 \%)$ & $\begin{array}{c}01 \\
(02.04 \%) \\
\end{array}$ & --- & $06(01.33 \%)$ & $06(01.33 \%)$ \\
\hline \multicolumn{3}{|c|}{$\begin{array}{l}\text { TOTAL NUMBER OF } \\
\text { ISOLATES }\end{array}$} & $\begin{array}{c}233 \\
(66.00 \%) \\
\end{array}$ & $\begin{array}{c}44 \\
(89.79 \%) \\
\end{array}$ & $\begin{array}{c}27 \\
(58.69 \%) \\
\end{array}$ & $304(67.85 \%)$ & $304(67.85 \%)$ \\
\hline
\end{tabular}

\section{Conclusion:-}

The monitoring and control of seafood quality is one of the main goals in the seafood industries. The findings of this study revealed that the raw seafoods sold in fish markets in the eastern province of Saudi Arabia could be a source of food borne bacterial pathogens. The presence of such contaminating bacteria could be attributed to cross contamination from the environment, source and unhygienic handling by the sellers. Hence, the findings of this study may be considered as an additional knowledge to enhance proper controlling of the storage and shelf life of seafoods by implementing preventive measures such as HACCP and application of Sanitation Standard Operating 
Procedures (SSOP) in fish markets to monitor the quality of seafoods by minimizing the prevalence of the pathogens.

\section{Acknowledgements:-}

Sincere thanks to Municipality officers, workers and vendors of Dammam Fish Market for their kind support during sampling for this study.

\section{References:-}

1. Austin, B and Austin D.A., 1985. Bacterial pathogens of Fish., Journal of Applied Bacteriology., 58: 483-506

2. Bakr WMK, Hazzah WA, Abaza AF, 2011: Detection of Salmonella and Vibrio species in some seafood in Alexandria. J A M Sci 7: 663-668.

3. Banwart, G., 1989. Basic Food Microbiol., $2^{\text {nd }}$ Ed. Pp. 312., An. Avi. Book., Published by Van Nostrand Reinhold., Newyork.

4. Biradar, R.S., OJHA, S.N., Ayyappan, S., and Salim, S.S., Fishing redefined, Times food processing journal., 2001. pp: $28-31$

5. Bryan, F.L., 1980. Food-borne diseases in the United States associated with meat and poultry., J. of Food Protect., 43: 140-150

6. Cohen, J and H. I. Shuval., 1973. Coliform, Fecal coliform and Fecal Streptococci as indicators of water pollution. Water Soil Pollution, 2: 85-95

7. Dos Santos, D.S., Solidonio, E.G., Costa, M.C.V.V., Melo, R.O.A., De souza, I.F.A.C., Silva, G.R., and Sena, K.X.F.R., 2015. Study of the Enterobacteriaceae group CESP (Citrobacter, Enterobacter, Serratia, Providencia, Morganella and Hafnia): A Review., The Battle against Microbial Pathogens: Basic Science., Technological Advances and Educational Programs (A. Mendez-Vilas, Ed)., pp. 794-805

8. Etzel, V., Meyer, C., Ballin, U., Krause, R., 1998. Investigation for the evaluation of Quality of Nile Perch after arriving at German wholesars. FSTA, 30 (12): 226

9. Falana, A.A., Determination of profiles of human bacteria pathogens in Nigerian fish and Seafood for Export., 2003. Proceedings of a final Research Coordination meeting held in Mexico city, Mexico., 22-26 July 2002., IAEA-TECDOC-1431

10. FAO: Corporate Document Repository., Quality aspects associated with Seafood.

11. FAO (Food and Agriculture Organization)., 1983. Support and Development of the Retail Trade in perishable Fishery products. pp 10-13 (Eddie, G. C. Edit), FAO fisheries technical paper No. 235 FIIU/T235

12. Figencetinkaya, TulayElalMus, Umutcelik., 2014. Occurrence of Vibrio, Salmonella and Staphylococcus aureus in retail fresh Fish, Mussel and Shrimp., ACTA VET. BRNO., 83: 73-78

13. Gram, L., Huss, H., H., 1996. Microbiological spoilage of fish and fish products. Int. J. Food Microbiol., 33: 121-137

14. Grimont, P.A.D. and Grimont, F., 1978. The genus Serratia.,Annu. Rev. Microbiol., 32: 221-248

15. Hui Liu, Junmin Zhu, Qiwen Hu, XiancaiRao, 2016. Morganellamorganii, a non-negligent opportunistic pathogen (Review)., International Journal of Infectious Diseases., 50 (2016): 10-17

16. Huss, H.H., Ababouch, L. and Gram, L., 2004. Assessment and management of seafood safety and quality. FAO Fisheries Technical Paper., No. 444., Rome

17. International Life Sciences Institute (ILSI) 2011. The Enterobacteriaceae and their significance to the food industry., LSI Europe Report Series., pp 49

18. KaleyTash, 2004. Rahnellaaquatilis Bacteremia from a suspected urinary source., Journal of Clinical Microbiology., May 2005., pp 2526-2528

19. Kumar R, Surendran PK, Thampuran W, 2009: Distribution and Genotypic characterization of Salmonella serovars isolated from tropical seafood of Cochin, India. J. Appl. Microbiol. 106: 515-524.

20. Mai F. Elsherief., Mohamed M. Mousa., HosamAbd El-Ghalil., Engy F. El-Bahy., 2014. Enterobacteriaceae associated with Farm Fish and Retailed Ones., Alexandria Journal of Veterinary Sciences., 42: 99-104

21. Maria Carla Liberto, Giovanni Matua, RossanaPuccio, Terera Lo Russo, Elena Colosima, Emanuel Foca, 2009. Six cases of sepsis caused by Pantoeaagglomerans in a teaching hospital., New Microbiologica., 32: 119-123

22. Olugbojo., Joseph, A., Ayoola., Simeon, O., 2015. Comparative studies of bacteria load in fish species of commercial importance at the Aquaculture unit and Lagoon front of the university of Lagos., International Journal of Fisheries and Aquaculture., Vol. 7 (4)., pp 37-46

23. Onyango, M.D., Sarah Wandili, Rose Kakai, Eliud, N.W., 2009. Isolation of Salmonella and Shigella from fish harvested from the Winam Gulf of Lake Victoria, Kenya., J. Infect. Developing Countries., 3 (2): 99-104 
24. Podschun, R., Fischer, A and Ullmann, Y., 2001. Characterisation of Hafniaalvei isolates from human clinical extra-intestinal specimens: Haemagglutinins, Serum resistance and Siderophore synthesis., J. Med. Microbiol., Vol. 50: 208-214

25. Podschun, R., Ullmann, U., 1998. Klebsiellaspp as nosocomial pathogens: epidemiology, taxonomy, typing methods and pathogenicity factor.,Clin. Microbiol. Rev., 11: 589-603

26. Popovic, N.T., Skukan, A.B., Dzidara, P., Coz-Rakovac, R., Strunjak-Perovic, I., Kozacinski, L., Jadan, M., Brlek-Gorski., 2010. Microbiological Quality of Fresh and Frozen Seafood caught of the Ardiatic coast of Croatia., Vet Med., 55: 233-241

27. Priyanka Rani Majumdar, BhaktaSupratimSarker, Swapan Chandra Dey, DebashishSaha, Ripon Kumar Adhikary and ShuvagatoMondal., 2014. Bacterial Hazards Especially Pathogenic to Human in Consumable Marine fishes of NoakhaliSadar, Bangladesh., American Journal of Food Technology

28. Rahkia, S., Schaberg, D., Johnson, S., 1998. Significance of Salmonella serotypes in fish.,Epidemiol. Infect., 125 (9): 1284-1288

29. Renat Albuquerque Costa., 2013. Escherichia coli in seafood: A brief overview., Advances in Bioscience and Biotechnology., 4: 450-454

30. Rodriguez, A.I., hariharan, H., Nimrod, S., 2011. Occurrence and Antimicrobial drug resistance of potential bacterial pathogens from Shellfish, including Queen Conchs (Strombusgigas) and Whelks (Cittarum pica) in Grenada., Web Med Central Microbiol., 2: WMC001943

31. Romero Jarero Jorge, PilarNegrete Redondo and Maria del Carmen MonroyDosta, 2016. Bacterial load comparison of marine fish collected and commercially obtained for human consumption in western region of Yucatan peninsula, Mexico., International Journal of Aquatic Science., Vol. 7., No. 1., 6-12

32. Rusul, G., MahyuddinDahan, M., Dollah, M., 1991. A survey of microbiological quality of fish sold in two local wet markets, Pertanika., 14 (3): 243-247

33. Sanaa O. Yagoub., 2009. Isolation of Enterobacteriaceae and Pseudomonas spp. from raw fish sold in fish market in Khartoum state., Journal of Bacteriology Research., Vol. 1 (7) pp 085-088

34. SehnazYasemin TOSUN., Didem UCOK Alakavak.,Suhendan, MOL., 2016. Isolation of Salmonellaspp and other members of Enterobacteriaceae from horse Mackerel (Trachurustrachurus), sold in public markets of Istanbul, Turkey., Journal of Food and Health Sciences., 2 (2): 82-89 (2016)

35. Shabarinath S, Kumar HS, Khushiramani R, Karunasagar I, 2007: Detection and Characterization of Salmonella associated with Tropical seafood. Int. J. Food Microbiol. 114: 227-233.

36. SureeratPhuvasate., 2008. Electrolyzed Oxidizing water Treatment as a Post-harvest Process for controlling histamine formation in fish., A thesis submitted to Oregon State university, in partial fulfillment of the requirements for the degree of Master of Science.

37. United Nations (2004): Global action for women towards sustainable and equitable development, Agenda 21, Chapter 24. United Nations Environment Programme.

38. USFDA BAM (Online), http://www.fda.gov/Food/FoodScienceResearch/LaboratoryMethods/ucm2006949.htm

39. Varnam, A.H., Evans, M.G., 1991. Food borne pathogens., Wolfe Publishing Ltd., Aylesbury., England.

40. Wekell, M.M., Manger, R., Colburn, K., Adams, A and Hill, W., 1994. Microbiological Quality of Seafoods: Viruses, Bacteria and Parasites., Shahidi F and Botta, J.R., Eds., Seafoods Chemistry, Processing technology and Quality, Chapman \& Hall, Glasgow., pp 220-232

41. Wogu, M.D., Maduakol, M., 2010. Evaluation of Microbial Spoilage of some aqua cultured fresh fish in Benin city, Nigeria., Ethiopian J. Environ. Studies Manag., 3 (36): 18-22 